\title{
THE WORKS OF CAFER AÇIN IN TURKISH ORGANOLOGY
}

\author{
Assist. Prof. Dr. Seher TETIKK IŞIK ${ }^{1}$
}

\begin{abstract}
Cafer Açın was born in Ankara in 1939, as stated in his autobiography. He began his main education in 1950, registering at the Department of Instrument Manufacturing for Secondary and High School Students at the Ankara Technical Teacher Training College, and then studied at the Ankara State Conservatory, where his department was transferred in 1957. According to his autobiography, he wrote poems, painted and composed about 30 songs. He often mentioned his teacher, Mithat Arman, in his works, a man who contributed greatly to both his education and personality. In this article, the works of Cafer Açın have been examined.
\end{abstract}

Keywords: Cafer Açın, enstrüman, otobiyografi.

\footnotetext{
${ }^{1}$ Gazi Üniversitesi Türk Müziği Devlet Konservatuvarı, sehertetik@gmail.com
} 


\title{
TÜRK ORGANOLOJISINDE CAFER AÇIN'IN ESERLERI
}

\begin{abstract}
ÖZET
Cafer Açın 1939 yılında Ankara'da doğmuştur. 1950 yılında Teknik Öğretmen Okulunun Enstrüman ( Müzik Aletleri) Yapım Bölümüne başlamış, bölümün 1957 yılında Ankara Devlet Konservatuarı'na nakledilmesi üzerine eğitimini orada tamamlamıştır. Otobiyografisine göre şiirler yazmış, resimler çizmiş ve yaklaşık 30 adet şarkı bestelemiştir. Birçok eserinde eğitimine ve kişiliğine önemli katkıları olan hocası Mithat Arman'ı anmıştır. Bu çalışmada, Cafer Açın'ın eserleri incelenmiştir.
\end{abstract}

Keywords: Cafer Açın, instrument, autobiography. 


\section{INTRODUCTION}

Academic education in instrument manufacturing dates back to the establishment of an Instrument Manufacturing Workshop at the Ankara State Conservatory (1936). An expert, Heinz Schafrat, was called in from Germany. Heinz Schafrat nurtured the talents of Necati Orbay, Abdullah Arseven and Mithat Arman (Açın, 1977: 59), and returned to his country after the beginning of Second World War in 1939 (Açın 163). Mithat Arman developed the Instrument Manufacturing Workshop at the Gazi Graduate School of Education after 1939; this then became the Department of Instrument Manufacturing. Although the department was closed down in 1943, and another Department of Instrument Manufacturing was opened at Ankara Technical Teacher's Training School (Açın 163), the opening date of that department remains unknown. As a matter of fact, it was said that there was a workshop where instruments were repaired and tuned up, and stringed instruments in particular were rebuilt, at the Ankara State Conservatory in 1941 (Gökyay, 1941: 38). Moreover, according to the payrolls published in the Official Gazette between 1940 and 1952, five people by the name of "instrument repairmen", one workshop chief and four assistants, were working at the Ankara State Conservatory. (Resmi Gazete, 1941: 1061). One of the last students and workers in this department was Cafer Açın (Açın, 1994: 24).

\section{The Life of Cafer Açın and his Instrument Manufacturing}

Cafer Açın was born in Ankara in 1939, as stated in his autobiography (Açın, 1994). While attending elementary school, he was influenced by his uncle Mehmet Altan, and he started to build instruments. At the age of eleven, he held his first enhibition of miniature instruments in the Exhibition Hall of the Faculty of Language, History and Geography, at Ankara University. This exhibition is important in that it indicates the love he already felt for his profession. He began his main education in 1950, registering at the Department of Instrument Manufacturing for Secondary and High School Students at the Ankara Technical Teacher Training College, and then studied at the Ankara State Conservatory, where his department was transferred in 1957. There he studied under Prof. Christian Schertel, Etienne Vatelot, Mithat Arman, Bahri Yakut, İbrahim Sakarya and Mahmut Ragip Gazimihal. After his graduation, he began work as a piano assistant at the Ankara State Conservatory in 1962. He represented Turkey at the International Violin Manufacturing Competition in 1967, 1972 and 1977; and received certificates and degrees in competitions. He was appointed to the Istanbul Turkish Music State Conservatory (TMSC) in 1976 as an instructor, and then became the head of the Department of Instrument Manufacturing when the conservatory was affiliated with Istanbul Technical University (ITU). 
He retired from his long-term duty at the ITU-TMSC Department of Instrument Manufacturing in 2005. He died on 4 September 2012. According to his autobiography, he wrote poems, painted and composed about 30 songs. He often mentioned his teacher, Mithat Arman, in his works, a man who contributed greatly to both his education and personality.

\section{His Exhibitions}

Cafer Açın held three exhibitons of his own instruments in Ankara, one at the Faculty of Language, History and Geography of Ankara University in 1950, one at the National Library in 1968, and one at the Exhibition Hall of the Ankara Ministry of Industry in 1973, before he was appointed to Istanbul TMSC; and there were two exhibitions after his appointment, one at the Atatürk Cultural Center in Izmir in 1981, and one at the Urart Art Gallery at the $11^{\text {th }}$ International Istanbul Festival in 1983. Moreover, he organized the department of music at the $18^{\text {th }}$ European Council Art Gallery within the Anatolian Civilizations Exhibition (Açın, 1994).

The Instruments of Cafer Açın: The instruments that Cafer Açın made in the light of the suggestions and directions of performers were as follows:

Mut: This is a chordophone which has a clearer sound than the oud and is easier to play and hold. It was made for Musa Kumral in 1963, and is first mentioned in the books, Instrument Science (Enstrüman Bilimi) and Oud Manufacturing (Ud Yapımı) (Açın, 1994).

Çağlar: This is a chordophone appropriate for electro and plain tambur, guitar and bağlama which was made for the Hikmet Taşan-Suna Teoman Duo in 1972; and it was mentioned in his book, Instrument Science (Enstrüman Bilimi) (Açın, 1994).

Yaren: This is a joint chordophone made for Özay Gönlüm in 1974, which combined three types of bağlama; and was mentioned in the books, Instrument Science (Enstrüman Bilimi) and Bağlama Manufacturing (Bağlama Yapımı) (Açın, 1994).

It was said that he manufactured another instrument called the Viguid as well as the Mut, the Çağlar and the Yaren however, there is no detailed information concerning this (Açın, 1994). Moreover, it has been suggested that he manufactured only one each of these instruments and that he did not mass-manufacture them. The improvements he made to the traditional instruments are explained in the concluding part of the present study. 
The piano studies he designed for the Turkish music sound system between the years 1971 and 1974 are known not to have been completed (Açin, 1994).

\section{Awards Bestowed on Cafer Açın:}

The International Violin Manufacturing Award (1972), the Award for Contribution to Forest Conservation (1981), the Award for Contribution to Education and Training (1991), the Boğaziçi Music Foundation Award (1996), the Traditional Motif Folklore Award (2000), the Turkish Music Service Award (2000), the Tangible Folklore Products Compilation Award (2000), the 50 ${ }^{\text {th }}$ Art Year Award (2000).

\section{Cafer Açın's Students:}

Cafer Açın was known to nurture the talents of many students and to have helped others who asked for his help when he was working at the Department of Instrument Manufacturing at ITU. Some of the students he nurtured have been working as instructors at various conservatories, especially the ITU Turkish Music State Conservatory, while many others have opened instrument manufacturing workshops all around the country. Of his students, Şafak Köksal and Ahmet Tunç Buyruklar work at the ITU Turkish Music State Conservatory; Veyis Yeğin and Aytaç Akarçay work at the State Turkish Music Conservatory in Ege University; Uğur Özek works at the Süleyman Demirel University; Ecevit Tunalı works at the State Conservatory in Mimar Sinan University; Arif Türker Gündoğdu works at the Ondokuz Mayıs University; and Zafer Güzey works at the State Conservatory in Anadolu University. Some students receiving education at the department of instrument manufacturing decided to specialize in certain instruments as well as learning how to manufacture them. His students, Ahmet Tunç Buyruklar, ${ }^{2}$ Uğur

\footnotetext{
${ }^{2}$ The theses of the students of Cafer Açın: Tunç Buyruklar. (1994). Klasik kemençenin tarihi gelişimi ve dört telli kemençenin yapımı. PhD Thesis, ITU Graduate School of Social Sciences, İstanbul; Sefer Açın. (1998) Türk halk müziği sazlarından bağlama ve kemanenin son yapım teknikleri. ITU Graduate School of Social Sciences, İstanbul; Zafer Güzey. (2000). Antonio Stradivari'nin keman yapımcilığındaki aşamalar. PhD Thesis, ITU Graduate School of Social Sciences, İstanbul; Veyis Yeğin. (1994). Kemanede yeni yapım teknikleri. PhD Thesis, ITU Graduate School of Social Sciences, İstanbul; Şafak Köksal. (1995). Kanun Tarihçesi-yapımı-mandal sistemi. PhD Thesis, ITU Graduate School of Social Sciences, Istanbul; Aytaç Akarçay. (1998). Türk halk müziği sazlarının sınıflandırılması, kullanıldığı yöreler ve türler. PhD Thesis, Ege University Graduate School of Social Sciences, Izmir; Gürkan Ortakale. (2007). Türk halk müziğinin klasik batı müziğine etkileri. $\mathrm{PhD}$ Thesis, Istanbul University Graduate School of Social Sciences, Istanbul; Oğuz Demir. (2002). Bağlamadaki eşik sistemi üzerinde yeni uygulama, PhD Thesis, ITU Graduate School of Social Sciences, Istanbul.
} 
Özek, Sefer Yücel Açın, Zafer Güzey, Ecevit Tunalı and Veyis Yeğin specialized in stringed instruments; Şafak Köksal specialized in plectrum instruments; Aytaç Akarçay specialized in oud manufacturing; and Arif Türker Gündoğdu specialized in guitar manufacturing.

Again, his students Arslan Çekiç, Bekir Sami Gül and Elif Zekiye Kızılhan manufacture ouds and tamburs; Aşkın Palamutçu, Erşen Aycan, Bülent Ateş, Gürkan Ortakale, Hamdi Can Türkel, Nimet Nilgün Ünsal, Oğuz Demir, Selim San, Seyrani Cihan, Soner Engin and Volkan Özkazanç manufacture and repair violins; Mustafa Copcuoğlu manufactures ouds; Rıfat Türen manufactures guitars; Zeynel Şahin manufactures bağlamas; and Tonguç Erol manufactures qanuns.

There are many instrument manufacturers who have stated that they were not his students but they benefited from his ideas. These are Dursun Demir, Kemal Eroğlu, Servet Hamzaoğlu, Ünal Şenpekmezci, Yusuf Toraman (bağlama), Fikret Işıkçı, Fikret Özer, Mustafa Çetinkaya, Süreyya Piriler (oud), Ali İnandım, Arif Boğadır, Çetin Akay, Ferhat Henden, Melih Serim (violin), Çetin Akay, Nural Yumlu (kemenche), Sedat Üstüntürk (tambur), Ahmet Erenler, Ahmet Sandıkçı, Vahide Tunca (string instrument), and Oktay Özkazanç (plectrum instrument) (Açın, 2003).

\section{Explanatory Presentation of the Works of Cafer Açın:}

Cafer Açın published and developed his first lecture notes for the benefit of the Turkish Music State Conservatory Protection Association. Some of his speeches were published, and some of them were not. The speeches he wrote are listed under the heading "Speeches" below. He made use of his own speeches and notes in his books later. Cafer Açın's speeches, articles and books are listed in chronological order below, without any orthographic changes to the names (The Turkish Language Association orthography was used in the descriptions; e.g. Tanbur-Tambur)

Cafer Açın, Instrument Knowledge (Enstruman Bilgisi), İstanbul: Turkish Music State Conservatory Protection Association publication, 1976, 30 p.; Instrument Knowledge included his lecture notes regarding the "Tanbur", "Various Tanburs", "Ranges and Factors", and "A Comparison of Sound Systems and Tanbur Construction". He then turned these notes into a book, Instrument Science (1994) in which the instruments were classified and described briefly. 
In his first speech at the Turcology Congress, he introduced his colleagues:

Speech: Cafer Açın, "Musical Instrument Manufacturers in Turkey and Our Musical Instruments", $2^{\text {nd }}$ International Turcology Congress Speech Abstracts $\left(2^{\text {nd }}\right.$ Istanbul, 4-9.10.1976), Ankara 1977, p. 59-61. bağlama:

At the Third Turcology Congress, he addressed the problems regarding the

Speech: Cafer Açın, "Standard Heights, Ratios, Ranges, Frequencies, Tensions and Pressures in Turkish Musical Instruments" $3^{\text {rd }}$ International Turcology Congress Program, Istanbul 1979, p. 46

Speech: The Cafer Açın's speech at the "Standard Heights, Ratios, Ranges, Frequencies, Tensions and Pressures of the Bağlama Family" seminar of the Ministry of Culture National Folklore Research Department (Ankara 28.04.1979) (Açın, 1994). This speech was then included in his bağlama book.

Speech: Cafer Açın's address, "Bağlama Arrangements", made at the III National Turcology Congress (Istanbul 6-10 October 1980). (Açın, 1994). This speech was then included in his bağlama book.

Four Cafer Açın speeches were published in the journals, the Journal of Music (Musiki Mecmuası) and Turkish Folk Music and Dances (Türk Halk Müziği ve Oyunlarl) in 1980-82:

Cafer Açın, “Our Forests and Instrument Manufacturing”, Music Journal, iss. 380, Istanbul 1980, p. 13-14

Speech: Cafer Açın's speech, “The construction, heights, ratios, tunes, frequencies, balances, sounds and sound ranges ney family" was given at the IV. National Turcology Congress (İstanbul 20 October 1981) (Açın, 1994). This speech was then included in his ney book.

Cafer Açın, "Treason to Turkish Nation”, Music Journal, iss. 383, Istanbul 1981, p. 12-14

Cafer Açın, "Important Issues Misunderstood about Insteruments", Music Journal, iss. 384, Istanbul 1981, p. 7-8 
Cafer Açın, "Bağlama and Its Family", Turkish Folc Music and Dances, iss. 3, 1982, p. 118-119; iss. 5, 1983, p. 216-218. The ideas contained in this speech were then included in his bağlama book.

He continued his speeches after publishing his above-mentioned three works.

Speech: Cafer Açın's speech, "The Development of Classical Klasik Kemençe" delivered at the ITU Turkish Music State Conservatory I: Turkish Music Symposium (Istanbul 21-23 December 1983) (Açın, 1994). This speech was then included in his kemençe book.

Speech: Cafer Açın, "Important Promlems in Our Music", Eskişehir Communication Sciences Faculty, Atatürk Musical Research and Education Center $1^{\text {st }}$ Turkish Music Congress, , $20^{\text {th }}-23^{\text {rd }}$ October1981, Eskişehir 1984, p. 1-3

Speech: Cafer Açın, "Standard Bağlama Family, The Effects of Bağlama Arrangements on Bağlama", $2^{\text {nd }}$ International Turkish Folclor Congress, Ankara 1983, p. 1-13. This speech was then included in his bağlama book.

Cafer Açın wrote the chapter, "The History and Presentation of Traditional Turkish Music Saz Family" for the World Music History project of UNESCO in 1983 (Açın, 1994). However, this project has not been completed according to Filiz Ali (Açın, 1995).

Speech: Cafer Açın participated in the National Handicraft Symposium with two speeches: Cafer Açın, "Turkish Art of Manufacturing Instrument", $I^{s t}$ International Handicraft Symposium, İzmir 1984, s. 1-11; Cafer Açın, "Turkish Art of Ornamenting Instrument", $I^{\text {st }}$ International Handicraft Symposium, İzmir 1984, p. 12-18. This last mentioned speech was then included in his ornamentation book.

Speech: Cafer Açın, "The Importance of Trees Used in Our Folcloric Instruments", $3^{\text {rd }}$ International Turkish Folclor Congress Speeches, Ankara 1987, p. 1-10. He repeated this information concerning trees in almost all of his books.

Speech: Cafer Açın's paper, "The Development of Instrument Manufacturing in Turkey" was given at the I. Music Congress (Ankara 14-18 June 1988) (Açın, 1994).

Speech: Cafer Açın, "Disorders in Our Tambur and Music", Balıkesir $1^{\text {st }}$ Turkish Music Symposium, Balıkesir 1998, p. 137-157 
He published his first book, Instrument Science: Organology in 1994; it was compiled from his first lecture notes:

Cafer Açın, Enstrüman Bilimi: Organoloji, İstanbul: Yenidoğan Basımevi, 1994, 500 s.; ayz.: Organoloji 2, İstanbul: Yenidoğan Basımevi, 1995, 205 p. As can be understood from the word "Instrument" in the title of the book, he refuses to use the word "çalgı", and he began his book by stating that the words "saz" and "instrument" should be used instead of "çalg1". He developed his book into Instrument Knowledge and wrote Instrument Science: Organology 18 years later. In this book of 500 pages, he evaluated the words "organology" and "çalgı", and explained instruments in groups of "percussion instruments (drum, davulbaz, deblek, goblet drum, halile, tambourine, daire, jazz tambourine, frame drum, kudüm, kös, timpani, chácaras, spoon, castanet, maraca, triangle, banjo, toumba, metronome, trap set; and xylophone and santur from melodic percussion instruments)", "wind instruments (kaval - dilsiz kaval ('kaval without a tongue'), dilli kaval ('kaval with a tongue') and two kavals, çığırtma, sipsi, zurna, mey, tulum (bagpipe), nefir, girift, ney, flute, oboe, bassoon, clarinet, saxophone, trumpet, horn, trombone, büğlü, tuba)", "plectrum instruments (komuz, bağlama family, yaren, tar (lute), tambur, oud, mut, lute, guitar, qanun, harp, çenk, lyre)", "stringed instruments (1klı̆g, hegit, rebab, stringed tambur, kemenche, sinekemani (breast fiddle), violin, viola, cello, double bass)", "clavier instruments (air claviers: organ, accordion, garmon, electronic claviers: epinet, harpsichord, percussion claviers: piano)". The chapters included balance and ratios, golden ratios, sound systems, frequency and ranges, acceleration in instruments, tension and pressure, sound ranges, Turkish music and Turkish instruments in World music, standards of Turkish instruments, manufacture and repair of instruments, and ornamental art and Turkish instruments. The book also includes an interview with the Canadian musicologist Irene Markoff, "You can challenge the world with your instrument" (pp. 102-103). The book Organology 2, which he published one year later, is almost like a summary of Instrument Science. However, following the chapters on the "manufacture and repair of instruments" and "how to protect instruments", the issues around instruments used in different music types, and music types according to the instruments, are explained.

In his book, Turkish Art of Ornamenting Instrument (İstanbul: Emek Basımevi, 1995, 123 p.; 2. bask1 2000), Cafer Açın addresses the following issues: "Saz Neck Ornaments", "Carved Soundholes of Meydan Sazı", "Carved Soundholes of Divan Sazı", "Carved Soundholes of the Bağlama", "Carved Soundholes of the Tambura", "Carved Soundholes of the Chonguri Cura", "Carved Soundholes of the Bağlama Cura", "Carved Soundholes of the Tambura Cura", "Soundholes of the Tambura, Bağlama and Divan Sazı", "Figured Soundholes of the Divan Sazı", 
"Figured Soundholese of the Bağlama", "Figured Soundholes of the Tambura", "Figured Soundholes of the Chonguri Cura", "Figured Soundholes of the Bağlama Cura", "Figured Soundholes of the Tambura Cura", "Qanun Patterns", "Qanun Side Patterns", "Qanun Soundholes", "Oud Patterns", "Oud Neck Patterns", "Oud Plectrum Patterns", "Sprayed Oud and Lute Soundholes", "Oud and Lute Soundholes", "Oud Soundholes", "Oud Soundholes that Should Be Ornamented with Pearls", "Small Oud Soundholes", "Oud and Bass Violin Soundholes", "Karlı Oud and Bass Violin Bow Soundholes", "Tenor Violin Bow Soundholes", "Violin Bow Soundholes" and "Rebab Soundholes".

In his book, Forms and Acustic Projections of Turkish and Western Instruments (İstanbul Emek Basımevi, 1995, 128 p., Cafer Açın addresses the following topics and issues: "Golden ratios in instruments", "Forms and acoustic projections of instruments", "Balance and ratios in instruments", "Frequencies and ranges of instruments", "Anatomies of instruments", "Sound ranges of instruments", "Tensions and pressures of instruments", and "Standard measurements of instruments (kudüm, mey, ney, bağlama, tar), tambur, oud, lute, qanun, violin bow, kemenche, stringe tambur, black sea kemenche, classical kemenche, violin)". Most sections in this book had been included in his previous book, Instrument Science (1994).

In his book, Clavier Instruments: Their History and Introduction: The Manufacture and Repair of the Piano (Tuşlu Sazlar ve Tarihçesi ve Tanıtımı: Piyano Yapım ve Bakımı) (İstanbul 1999, 204 p.), Cafer Açın addresses the following topics and issues: "The History and Introduction of Clavier Instruments", "Air Claviers (organ, accordeon, garmon)", "Electronic Claviers (electronic organ, electronic piano)", "Plectrum Claviers (epinet, harpsichord)", "Percussion Claviers (piano)", "Claviers Used between the sixteenth century and the nineteenth century (organo, virginale, spinetta, cembalo, clavicembalo, clavicordo, fortepiano, pianoforte a. griffa)", "The World's Famous Pianos", "Turkish Pianos", "The Manufacture of the Piano", "Images of Piano Manufacturing", "The Repair of the Piano", "Anatomic Parts of the Piano", "Tools used in the Manufacture of the Piano", and "Trees and their Properties as Used in the Manufacture of the Piano".

Cafer Açın, Guitar Manufacturing Art and Guitar Artists (İstanbul 1999). After formerly addressing the issue of the guitar in Instrument Science, Cafer Açın here explains "guitar types, guitar anatomy, guitar balance and ratios, guitar frets, and the manufacture of the classical guitar" (Enstrüman Bilimi, p. 140-148, 263, 389). He used the same images in his book, Forms and Acoustic Projections of Turkish and Western Instruments (Türk ve Batı Enstrümanlarının Form ve Akustik 
Projeleri) (p. 29, 52, 77, 90). The Art of Guitar Manufacturing is thought to have been compiled from all of the above-mentioned sources.

Cafer Açın addresses the issue of the bağlama in his book, The Art of Bağlama Manufacturing and Bağlama Artists (Bağlama Yapım Sanatı ve Sanatçılarl) (İstanbul: Emek Basımevi, 2000, 472 p.). The book is comprised of the following chapters: "The Origin of Stringed Instruments", "Komuz", "The Bağlama and the Bağlama Family", "The Bağlama Family", "The Anatomy of the Bağlama", "The Sound Range of the Bağlama Family", "Bağlama Arrangements", "The Effects of Bağlama Arrangements on the Bağlama", "Yaren", "Golden Ratios in Instruments", "Form and Acoustic Projections of the Bağlama", "The Balance and Ratios of the Bağlama", "The Frequency and Ranges of the Bağlama", "Tensions and Pressures in Instruments", "Tension and Pressure in the Bağlama Family", "Carved Instrument Manufacturers", "The Transition Period to Figured Instruments", "The Importance of Figured Instruments in the Bağlama Family", "The Manufacture of the Bağlama", "Images of Bağlama Manufacturing", "The School of the Bağlama", "The Capital of the Bağlama", "Artists Album", "Manufacturing Artists", "Performing Artists", "Developments in the Bağlama in the Last Fifty Years", "The Systems used by the Masters of Instruments", "Balance and Ratios in Instruments of the Bağlama Family", "Various Forms of the Bağlama", "The Importance of Curve", "Sound Holes in the Bağlama", "Development of the Pegbox in the Neck of the Instrument", "Wiggle Room in the Neck of the Bağlama", "Bağlama Frets", "Fret Division", "Creating Standards in the Instruments of the Bağlama Family"), "Biography and Interviews", "Turkish Instruments: the Art of Manufacturing", "Turkish Art of Ornamenting Instruments", "The Patterns, Motifs and "The Soundhole Images of Cafer Açın", "Tools Used in the Manufacture of Instruments", "Trees Used in the Manufacture of Instruments" and "A General Introduction to the Tar". The book also includes the writing, "Dreams Came True" ("Rüyalar Gerçek Oldu) by Erdoğan Sevgin of the newspaper, Sabah, the poem "Bağlama" by Turgut Günay and the interview with Irene Markoff, "You Can Challenge the World with Your Instrument".

In his book, The Art of Oud Manufacturing and Oud Players (Ud Yapım Sanatı ve Sanatçıları) (İstanbul: Emek Basımevi, 2000, 356 p.), Cafer Açın addresses the following topics and issues: "The Oud", "The Mut", "The Lute", "Fret Ranges of the Lute", "The Anatomy of the Lute", "Standard Lute Family Measurements", "Standard Oud Family Measurements", "The Sound Range of the Oud", "Golden Ratios in Instruments", "Acoustic Forms of the Oud and Lute", "Balance and Ratios of Instruments", "Balance and Ratios of the Oud and Lute", "Tensions and Pressures in Instruments", "Tension and Pressure in the Oud", "Oud 
Manufacturing", "The Sound Table and Balcony System in the Oud", "Images of Oud Manufacturing", "Artists Album", "Manufacturing Artists", "The Art of Turkish Instrument Manufacturing", "Turkish Art of Ornamenting Instruments, "Tools Used in the Manufacture of Instruments", "Trees Used in the Manufacture of Instruments", and "Oud Boxes".

In his book, Classical Kemenche, The Art of Kemenche Manufacturing and Kemeche Artists (Klâsik Kemençe, Yapım Sanatı ve Sanatçılart) (İstanbul Emek Basımevi, 2001, 382 p.), Cafer Açın addresses the following topics and issues: "The Classical Kemenche", "The Development of the Classical Kemenche", "The Fourstringed Classical Kemenche Family", "The Anatomy of the Classical Kemenche", "A Comparison of Kemenches", "Standard Classical Kemenche Family Measurements", "The Sound Range of Classical Kemenches", "From the Classical Kemenche to the Violin", "Balance and Ratios in Instruments", "Balance and Ratios in the Classical Kemenche", "Golden Ratios in Instruments", "Form and Acoustics in the Classical Kemenche", "Tensions and Pressures in Instruments", "Tensions and Pressures in the Instruments of the Classical Kemenche Family", "Classical Kemenche Manufacturing", "Images of Classical Kemenche Manufacturing", "The Classical Kemenche Statement of Cüneyt Orhon", "First Development Movements", "Development in Certain Instruments which are Parallel to the Change in the Kemenche", "The Equalization of String Lengths", "Education at ITU TMSC", "A Comparison of Three- and Four-stringed Kemenches", "Views on the Four-stringed Kemenche", "Strings Used in Kemenches", "The Positions of Three- and Fourstringed Kemenches", "Memories of the Kemenche", "Artists Album", "Performing Artists", "The Art of Manufacturing Turkish Instruments", "Turkish Instruments: Ornamenal Art", "Pattern Motif Images that Cafer Açın Drew and Made for the Classical Kemenche", "Tools Used in the Manufacture of Instruments", "Trees Used in the Manufacture of Instruments and Their Properties", and "Other Stringed Instruments That Are Not Used in Turkish Music (1kll̆ğ, kemenche, kemançe, boğumlu kemane, heğit, rebab, stringed tambur, black sea kemenche)". The works of Cafer Açın on creating the kemenche family reminds some works of Hüseyin Saadettin Arel on kemenche quintet. Cafer Açın stated that he was unaware of $\mathrm{H}$. Sadettin Arel's studies when he was working on his own book about the kemenche family (Açın, 2001).

Cafer Açın made use of the ideas and opinions of Cüneyd Orhon regarding the development of the kemenche, and stated that he met Arel in 1948, and Arel had knowledge in this field. Cüneyd Orhon stated that he met Cafer Açın in 1972 and that they talked about the equalization of kemenche strings, which indicated that Açın was not aware of Arel's studies. Orhon stated that they had the opportunity to 
conduct studies concerning the establishment of the conservatory Orhon also stated that "I want to discuss the equalized four-stringed kemenche of Arel one more time"(Aksoy, 2010), which, again, indicated that Cafer Açın also noticed that there were constraints attached to the kemenche and he wanted to work on them, and that he was affected by Cüneyd Orhon, who also shared the views of Arel.

In his book, The Art of Tambur Manufacturing and Tambur Artists (İstanbul: Bilgi Basımevi, 2002, 338 p.), Cafer Açın addresses the following topics and issues: "Tambur", "The Anatomy of the Tambur", "The Tambur Scheme", "The Subhi Ezgi and Arel System", "Fret Ranges of Fifty-six Transposition", "Fret Ranges of Sixtyfive Transposition", "The Sound Range of the Tambur", "Golden Ratios in Instruments", "Acoustic Forms of the Tambur", "Balance and Ratios in Instruments", "Balance and Ratios in the Tambur", "Sound Systems in Music", "Inverse Proportion in Music", "Intermediate Frequencies", "Chromatic Sound Frequencies", "Sound Horns", "The Tuning Fork", "The Tuning Fork Problem", "Curve in Instruments", "Tension and Pressures in Instruments", "Tambur Manufacturing", "Images of Tambur Manufacturing", "Artists Album", "Manufacturing Artists", "Famous Tambur Artists of Old Times", "Performing Artists", "The Stringed Tambur and Tambur Artists", "Stringed Tambur", "Famous Stringed Tambur Artists", "Two Legendary Tambur Artists of Old Times", "Famous Tambur Artists of Today, "The Art of Turkish Instrument Manufacturing", "Turkish Art of Ornamenting Instruments", "Tools Used in the Manufacture of Instruments", and "Trees Used in the Manufacture of Instruments and Their Properties".

In his book, The Art of Qanun Manufacturing and Qanun Artists (İstanbul: Bilgi Basımevi, 2003, 387 p.), Cafer Açın addresses the following topics and 1ssues: "The Qanun", "The Sound Range of the Qanun", "The Anatomy of the Qanun", "The Anatomic Parts of the Qanun", "Instruments Like the Qanun", "Fârâbî", "Cafer Açın Theory" "Golden Ratios in Instruments", "The Acoustic Form of the Qanun", "Tension and Pressures in Instruments", "Tension and Pressures in the Qanun", "The Sound System in Music", "Inverse Proportion in Music", "Coma Frequencies", "Chromatic Sound Frequencies", "Sound Horns", "The Tuning Fork", "The Tuning Fork Problem", "Curve in Instruments", "Qanun Manufacturing", "Images of Qanun Manufacturing", "Artists Album", "Manufacturing Artists", "Performing Artists", "The Art of Turkish Instrument Manufacturing", "Turkish Art of Ornamenting Instruments", "Tools Used in the Manufacture of Instruments", and "Trees Used in the Manufacture of Instruments and Their Properties". He mentioned issues concerning the "proportioning method or theory", a theory he came up with and used for the first time in this book. He wrote that, "Vertical lines drawn at equal intervals from the corner of an acute angle to an edge constitute the folds of the first 
vertical line". This theory was proved in 1957, and used as a proportioning method in making the instruments bigger or smaller. It is also used in architecture and cartography. Moreover, Cafer Açin included the article, "An Examination of the History of the Qanun" by Haluk Güneyli, the writing of İsmail Şençalar on why he wrote the qanun method, the explanation of Nevzat Sümer regarding the peg plan of the qanun, and the writings, "Multiple Sounding of Turkish Music" and "53 Tools of Easy Transmission to Coma" by Ahmet D. Sandıkçı.

In his book, Turkish Instrument Manufacturing Art and Artists (Türk Enstrüman Yapım Sanatı ve Sanatçıları) (İstanbul: Bilgi Basımevi, 2003, 620 p.), Cafer Açın addresses the following topics and issues: "The Art of Turkish Instrument Manufacturing", "Turkish Art of Ornamenting Instruments", "Golden Ratios in Instruments", "Plans and Projects of Instruments", "Balance and Ratios in Instruments" "Anatomies of Instruments", "Fret Ranges and Frequencies in Instruments", "Standard Turkish Instruments", "Tension and Pressures in Instruments", "Sound Ranges of Instruments", "Images of Bağlama Manufacturing", "Images of Tambur Manufacturing", "Images of Oud Manufacturing", "Images of Qanun Manufacturing", "Images of Guitar Manufacturing", "Images of Classical Kemenche Manufacturing", "Images of Violin Manufacturing", "Images of Turkish Piano Manufacturing", "Artists Album", "Bağlama Manufacturing Artists", "Tambur Manufacturing Artists", "Oud Manufacturing Artists", "Qanun Manufacturing Artists", "Guitar Manufacturing Artists", "Classical Kemenche Manufacturing Artists", "Violin Manufacturing Artists", "Piano Manufacturing Artists" and "Trees Used in the Manufacture of Instruments and Their Properties.

In his book, The Art of Violin Manufacturing and Artists (Keman Yapım Sanatı ve Sanatçıları) (İstanbul: Bilgi Basımevi, 2005, 447 p.), Cafer Açın addresses the following topics and issues: "Sinekeman", "From Classical Kemenche to the Violin", "The Violin", "The Viola", "The Cello", "The Double Bass", "The Sound Range of the Violin Family", "The Anatomy of the Violin", "Balance and Ratios in the Violin Family", "Golden Ratios in Instruments", "Tension and Pressures in the Violin Family", "Important Problems Regarding Stringed Instruments", "Violin Manufacturing", "Stages of Violin Manufacturing", "Images of Violin Manufacturing", "Artists Album", "Violin Manufacturing Artists", "The World's Most Famous Violin Manufacturers", "Famous Violin Manufacturers", "Performing Artists", "The Art of Turkish Instrument Manufacturing", "Turkish Art of Ornamenting Instruments", "The Anatomic Parts of the Violin", "Tools Used in the Manufacture of Instruments", and "Trees Used in the Manufacture of Instruments and Their Properties". 
In his book, The Art of Mandolin Manufacturing (Mandolin Yapım Sanatl) (İstanbul: Bilgi Basımevi, 2005, 168 p.), Cafer Açın addresses the following topics and issues: "The Mandolin", "Tunings of the Mandolin Family", "The Sound Range of the Mandolin Family", "The Anatomy of the Mandolin", "Mandolin Manufacturing", "Stages of Mandolin Manufacturing", "Images of Mandolin Manufacturing", "The Art of Turkish Instrument Manufacturing", "Turkish Art of Ornamenting Instruments", "Tools Used in the Manufacture of Instruments", and "Trees Used in the Manufacture of Instruments and Their Properties".

In his book, The Art of Ney Manufacturing and NeyArtists (Ney Yapım Sanatı ve Sanatçıları) (İstanbul: Bilgi Basımevi, 2006, 246 p.), Cafer Açın addresses the following topics and issues: "Ney, Başpâre, Parazvâne, Girift", "Research and Studies Concerning the Ney", "The Anatomy of the Ney", "The Ney Family", "The Sound Range of the Ney Family", "Sound Systems in Music", "Turkish Music Maqams", "Frets", "Frequencies", "The Diapason", "Ney Manufacturing", "Standard Ney Lengths and Fret Ranges", "Balance and Ratios in the Ney", "Sounds of the Sound Holes of the Ney", "Determination of the Tone in Wind Instruments", "The Tones of the Ney and Diapason Sounds", "Sound Horns", "The Opinions, Ideas and Suggestions of Artists (the opinions and thoughts of Sencer Derya on the Ney and Neyzens (Ney Performers) from the Pen of Aziz Şenol Filiz", "Ney Manufacturing Through the Tuning Method" and "Başpâre Manufacturing" by Eymen Gürtan, ", "The Thesis of İhsan Tür Regarding the Fret Ranges of the Ney”, "Suggestions from Mehmet Yücel for Young Neyzens)", "Artists Album", "Ney Manufacturing Artists", "Performing Artists", "Neyzens and Their Students", "The Love of the Ney Among Young People", "The Art of Turkish Instrument Manufacturing", and "Turkish Art of Ornamenting Instruments". This book is considered to be derived from his previous reflections concerning the ney (Açın, 1981).

Açın stated that he wrote "34 books on instrument science and manufacturing"; (Açın, 2005) however, he included only the covers of the books mentioned in the present article in the books he wrote; neither the names nor the covers of his other books were included in any of the biographies of him. ${ }^{3} \mathrm{He}$ also stated that he was still writing a four-volume book called "The Art of Manufacturing

\footnotetext{
${ }^{3}$ E.g. He said that "People can make use of my book Piano Tuning Adjustments" (Açın. (1999). Tuşlu Sazlar. p. 80); however, such a book was never mentioned in any of the biographies of him. On the other hand, in the references in his book Instrument Science (1994), he mentioned two other books, Turkish Folk Music Instruments (Ankara, 1982) and Traditional Turkish Instruments (Ankara, 1984), which, again, appear not to have been published. These are thought to be the writings he prepared for the Unesco project.
} 
Stringed Instruments", "The Art of Manufacturing Plectrum Instruments", , "The Art of Manufacturing Classical Instruments: and "The Art of Manufacturing Wind Instrument". It is known that his books were produced via photocopy, and not by a printing house.

In his books, Cafer Açın addresses musicians who manufacture instruments and perform their instruments efficiently and he sometimes mentions his children, teachers or virtuosos at the beginning of his books. However, the fact that certain sections are always repeated without any changes in many of his books resulted in many unnecessary repetitions. Among these repeated sections are "The Art of Turkish Instrument Manufacturing", "Turkish Art of Ornamenting Instruments", "Tools Used in the Manufacture of Instruments", "Trees Used in the Manufacture of Instruments", "The Golden Ratio in Instruments", "Tension and Pressures in Instruments", "Sound Ranges in Instruments", "Balance and Ratios in Instruments", "Acceleration in Instruments", "Patterns, Motifs and Soundhole Images", "Frequency and Fret Ranges in Instruments", "Anatomies of Instruments", "Standard Turkish Instruments", "Frequencies", "The Diapason", "The Diapason Problem", "Sound Horns", "Coma Frequencies", "Chromatic Sound Frequencies", "Sound Systems in Music", "Inverse Proportion in Music" and "Turkish Music Maqams". The section on the trees used in the manufacture of instruments was included in almost all of his research works. Although he did not mention Adnan Berkel's book, Wooden Material Technology (Ăgaç Malzeme Teknolojisi) in his bibliography, he used most of the information in that book in his own works, without making any changes (Berkel, 1971:145). The reason why he constantly repeated information could be due to the fact that he was not familiar with book writing techniques.

In his works called The Piano, The Bağlama, The Qanun, The Violin, The Classical Kemenche, The Ney, The Tambur, Oud Manufacturing Art and Artists, which aimed at explaining these instruments one by one, the sections "Artists Album", "Manufacturing Artists" and "Performing Artists" were introduced. These works generally included issues such as the anatomies of the instruments he mentioned, their anatomic parts, sound ranges, forms and acoustic projections, balance and ratios, frequency and fret ranges, tension and pressures, pattern and motif images, and standard measurements; images of the manufacture of each instrument were also included.

The topics, "The Forms and Acoustic Projections of Instruments" and "Anatomies of Instruments" were collected to form The Forms and Acoustic Projections of Turkish and Western Instruments (Türk ve Batı Enstrümanlarinin Form ve Akustik Projeleri), the parts within "Motifs and Patterns in Instruments" 
were collected to form Turkish Art of Ornamenting Instruments (Türk Enstrüman Süsleme Sanat), and the issues around "Plans and Projections of Instruments", "Anatomies of Instruments" and "The Images of Instrument Manufacturing" were collected to form Turkish Instrument Manufacturing Art and Artists.

Classification of Instruments: Cafer Açın wrote no specific article regarding the classification of instruments, a problematic issue in Turkish organology. Moreover, he classified instruments under five groups, percussion instruments, wind instruments, plectrum instruments, stringed instruments and clavier instruments, in his book Instrument Science: Organology and Organology 2 (Açın, 1994: 16). He also classified percussion instruments as percussion and melodic percussion instruments; wind instruments as wooden and metal or reed and mouthpiece wind instruments; and clavier instruments as air clavier instruments, electronic clavier instruments, plectrum instruments and percussion clavier instruments. (Açın, 1999) 4 For the names he gave to instruments in his classification, his book, Instrument Science (Enstrüman Bilimi (1994) may be consulted.

\section{CONCLUSION:}

\section{The Contributions of Cafer Açın toTurkish Organology:}

Cafer Açın made great contributions to the manufacture of instruments with the speeches he gave at conferences, his addresses at national and international congresses, in the conventions and symposiums he participated in, the articles he published, the competitions he participated in and the exhibitions he held. There were some efforts towards the standardization of instruments, but all these standardizations were considered to be not right as they came "out of the blue"; and Yalçın Tura and Cahit Atasoy refused this kind of standardization in their articles. However, as a manufacturer of Turkish musical instruments, Cafer Açın made efforts to standardize Turkish musical instruments, to determine the fret ranges, sound ranges, balance, ratio, tension and pressures, and to introduce the techniques used in the manufacture of instruments. Conducting all of these studies, he sought the opinions of his colleagues, TRT radio artists and performers, and held discussions with them. He took the advice of Nevzat Sümer; Muzaffer Sarısözen and Şenel Önaldı; Halil Aksoy; Cüneyd Orhon; Aka Gündüz Kutbay, Niyazi Sayın, Sencer Derya, Aziz Şenol Filiz, İhsan Tür and Eymen Gürtan regarding the qanun, bağlama, oud, kemenche, and ney, respectively (Açın, 1999:13-14).

\footnotetext{
${ }^{4}$ Açın. (1999). Tuşlu Sazlar Tarihçesi ve Tanıtımı. s. 15.
} 
His works included innovative approaches that would help the instruments to be performed individually and within a group such as the stringing qanun (1950), determining the standard lengths, fret ranges, fret frequencies, balance and ratios, and determining the places of the sound holes of the bağlama family (1953-1954), positioning the strings on ouds (1954-1955), making a new tambur using wooden material instead of metal for the ribs and leather instead of a wooden soundboard (1973), equalizing the lengths of the strings of the classical kemenche, extending the sound range by adding a fourth string, thus enabling a clearer sound, placing a metal piece at the bottom of the instrument in order to make it easier to play on the knee, thus creating the kemenche family (1974), standardizing the manufacture of the kemenche (1975), determining the tunes, lengths, names, balance, ratios and fret ranges of the ney (1976), standardizing the form, neck and string lengths of the bağlama (1978-1979), plugging a sound cable to the kemane, thus creating a new kemane, developing the alto kemane (1978), creating the kemane family (1980), and stretching the leather of the kudüm on a wooden bowl with screws (1984).

Cafer Açın opened courses using his own means in order to create a standard that would be implemented all around the country, he sent the plans, projects and manufacture techniques of the instruments he drew to people who were unable to participate in these courses, and he published various works of research, including those above-mentioned, at his own expense (Açın, 1977: 61). Many researchers are known to have made use of the studies of Açın concerning instrument manufacture (Copcuoğlu, 1993: 98-99). Moreover, Eren Özek published an article in which he explained the measurement methods using a simple and understandable language in order to enable the common use of the balance and ratios as determined by Açın (Özek, 2005).

Cafer Açın prepared plans and projects for a piano to play Turkish Music, and invented new stringed instruments called the "mut", the "yaren" and the "çağlar" in the light of the suggestions and opinions of performers.

It is clear that Cafer Açın broke new grounds in many of his works concerning the manufacture, standardization and development of many instruments. Yılmaz Öztuna placed Cafer Açın at the top of the list in his music encyclopedia; M. Nazmi Özalp included a biography of Açın in Turkish Music History (Türk Musikisi Tarihi); Şenel Önald 1 mentioned him as "A person who manufactured almost all Turkish musical instruments, and the piano, stringed instruments and the guitar from the western musical instruments, in the best way" in his encyclopedia; (Önald, 1977) and Murat Bardakçı said that he was "a very valuable luthier of our time"(Bardakç1, 1980). The fact that he developed the kemenche and he was a valuable luthier was mentioned in the book, The Manufacture of Musical 
Instruments and Instrument Drawings (Müzik Aletleri Yapımı Enstrüman Çizimi) of the Ministry of National Education published within the Vocational Education Development Project (MEB, 2006). The present study is not a complete evaluation of the works of Cafer Açın; however, researchers and academics who are interested in organology and instrument manufacturing should examine the issues of ratio, balance, instrument manufacturing measurements and fret measurements as introduced by Cafer Açın. 


\section{REFERENCES}

Açın, Cafer. Bağlama Yapım Sanatı ve Sanatçıları. İstanbul: Emek, 2000.

Açın, Cafer. Enstrüman Bilimi: Organoloji. İstanbul: Yenidoğan, 1994.

Açın, Cafer. Kanun Yapım Sanatı ve Sanatçıları. İstanbul: Bilgi, 2003.

Açın, Cafer. Keman Yapım Sanatı ve Sanatçıları. İstanbul: Bilgi, 2005.

Açın, Cafer. Klâsik Kemençe, Yapım Sanatı ve Sanatçıları. İstanbul: Emek, 2001.

Açın, Cafer. Mandolin Yapım Sanatı. İstanbul: Bilgi, 2005.

Açın, Cafer. Ney Yapım Sanatı ve Sanatçıları. İstanbul: Bilgi, 2006.

Açın, Cafer. Organoloji 2. İstanbul: Yenidoğan, 1995.

Açın, Cafer. Tanbur Yapım Sanatı ve Sanatçıları. İstanbul: Bilgi, 2002.

Açın, Cafer. Türk Enstrüman Süsleme Sanatı. İstanbul: Emek, 1995.

Açın, Cafer. Türk Enstrüman Yapım Sanatı ve Sanatçıları. İstanbul: Bilgi, 2003.

Açın, Cafer. Türk ve Batı Enstrümanlarının Form ve Akustik Projeleri. İstanbul: Emek, 1995. Asl1, 1999.

Açın, Cafer. Tuşlu Sazlar Tarihçesi ve Tanıtımı, Piyano Yapım ve Bakımı. İstanbul:

Açın, Cafer. Ud Yapım Sanatı. İstanbul: Emek, 2000.

Açın, S. Yücel. "Türk Halk Müziği Sazlarından Bağlama ve Kemanenin Son Yapım Teknikleri". Yayımlanmamış Doktora Tezi, İstanbul: İstanbul Teknik Üniversitesi Sosyal Bilimler Enstitüsü, 1998.

Açın, S. Yücel. "Türk Halk Müziği Sazlarından Kabak Kemane’nin Doğuşu, Yapımı ve Ailesinin Oluşması". Yayımlanmamış Yüksek Lisans Tezi, İstanbul: İstanbul Teknik Üniversitesi Sosyal Bilimler Enstitüsü, 1993.

Aksoy, Bülent. Cüneyd Orhon Anlatıyor, Radyo Günlerim. İstanbul: Pan, 2010.

Altıparmak, Cem. "Türk Mûsikîsinde Rebap ve Yapımında Standartlaşma". Yayımlanmamış Yüksek Lisans Tezi, İstanbul: İstanbul Teknik Üniversitesi Sosyal Bilimler Enstitüsü, 2007. 
Atasoy, M. Cahit. "Müzikte Standardizasyon". Orkestra 1.131 (1988): 49-54.

Balcı, Aydın. "Geçmişten Günümüze Karadeniz Kemençesi ve Yapımı Üzerine Çalışma". Yayımlanmamış Yüksek Lisans Tezi, İstanbul: İstanbul Teknik Üniversitesi Sosyal Bilimler Enstitüsü, 2001.

Bardakçı, Murat. "Günümüzün Çok Değerli Lutiyesi Cafer Açın ile Bir Konuşma". Musiki Mecmuası 1.371 (1980): 6-8.

Berkel, Adnan. Ağaç Malzeme Teknolojisi. İstanbul: Kutulmuş, 1970.

Buyruklar, Tunç. "Klasik Kemençenin Tarihi Gelişimi ve Dört Telli Kemençenin Yapımı". Yayımlanmamış Yüksek Lisans Tezi, İstanbul: İstanbul Teknik Üniversitesi Sosyal Bilimler Enstitüsü, 1994.

Copcuoğlu, Haluk. "İstanbul'da Profesyonel Bağlama Yapımcılar ve Teknik Özellikleri". Yayımlanmamış Yüksek Lisans Tezi, İstanbul: İstanbul Teknik Üniversitesi Sosyal Bilimler Enstitüsü, 1998.

Gökyay, Orhan Şaik. Ankara Devlet Konservatuarı Tarihçesi. Ankara: Maarif Vekaleti, 1941.

İyigün, Naim. "Çalgı Yapımında Meyve Ağaçları". Meyve Kitabı. Ed. Gürsoy Naskali, Emine. İstanbul: Kitabevi, 2006. 437-446.

Kalender, Necdet. "Çalgı Yapım, Bakım ve Onarımı". Uludağ Üniversitesi Eğitim Fakütesi Dergisi 1.1 (2001): 159-166.

Köksal, Şafak. "Kanun (Tarihçesi-yapımı-mandal Sistemi)". Yayımlanmamış Yüksek Lisans Tezi, İstanbul: İstanbul Teknik Üniversitesi Sosyal Bilimler Enstitüsü, 1995.

Milli Eğitim Bakanlığı. Müzik Aletleri Yapımı, Enstrüman Çizimi Iı. Ankara: Meb, 2006.

Önaldı, Şener. Türk Halk Musikisi Ansiklopedisi. Ankara: Yy, 1977.

Oter, Tolga. "Geçmişten Günümüze Ud Yapımcıları, Ud Yapımında Kullanılan Yöntemler". Yayımlanmamış Yüksek Lisans Tezi, Konya: Selçuk Üniversitesi Sosyal Bilimler Enstitüsü, 2007.

Özek, Eren. "Türk Enstruman Yapım Sanatında Oran ve Denge". Müzik ve Bilim 3.3 (2005): 17-35. 
Özgür, Zeliha. "Kanun Çalgısının Üretim Aşamaları ve Yapımında Kullanılan Ahşap Malzemenin Seçimi". Yayımlanmamış Yüksek Lisans Tezi, Ankara: Gazi Üniversitesi Sosyal Bilimler Enstitüsü, 2006.

Özkazanç, Rıza Oktay. Müzik Aletleri Yapımında Kullanılan Yerli Ağaç Türlerimizin Yayılış1, Teknolojik ve Akustik Özellikleri Üzerine Araştırmalar. Bartın: Yy, 2005.

Öztuna, Yılmaz. Türk Musikisi. Ankara: Orient, 2006.

Resmi Gazete, 02. 06. 1941, iss. 4848, p. 1061.

Resmi Gazete, 01. 06. 1942, iss. 5120, p. 3009-3010.

Resmi Gazete, 01. 06. 1943, iss. 5418, p. 5195-5196.

Resmi Gazete, 01. 06. 1944, iss. 5719, p. 7019-7020.

Resmi Gazete, 01.06 1945, iss. 6020, p. 8764-8765.

Resmi Gazete, 31.12.1945, iss. 6194, p. 9838-9839.

Resmi Gazete, 02.01.1947, iss. 6795, p. 13386- 13387.

Resmi Gazete, 01.02.1949, iss. 7144, p. 15650-15651.

Resmi Gazete, 01.03.1952, iss. 8048, p. 1952-1953.

Resmi Gazete, 20.08.1965, iss. 12080, p. 6-7.

Resmi Gazete, 15.07. 1972, iss. 14246, p. 8-9.

Sarı, Ayhan. Asri Kemençe Dr. Zühtü Rıza Tinel. İstanbul: İtü, 2008.

Şükûn, Kâmil. Günümüz Türkiye'sinde Kim Kimdir?. İstanbul: Profesyonel, 2002.

Tura, Yalçın. "Müzikte Standardizasyon". Orkestra 130.130 (1988): 30-38.

Tura, Yalçın. Türk Musikisinin Meseleleri. İstanbul: Pan, 1988.

Uçan, Ali. İnsan ve Müzik, İnsan ve Sanat Eğitimi. Ankara: Evrensel, 2005. 